\title{
G Protein-Activated Inward Rectifier Potassium Channel 4
}

National Cancer Institute

\section{Source}

National Cancer Institute. G Protein-Activated Inward Rectifier Potassium Channel 4. NCI Thesaurus. Code 195840.

G protein-activated inward rectifier potassium channel 4 (419 aa, $\sim 48 \mathrm{kDa}$ ) is encoded by the human KCNJ5 gene. This protein is involved in regulated ion transport. 